\title{
Historein
}

Vol 14, No 1 (2014)

On the Edge of History and Philosophy

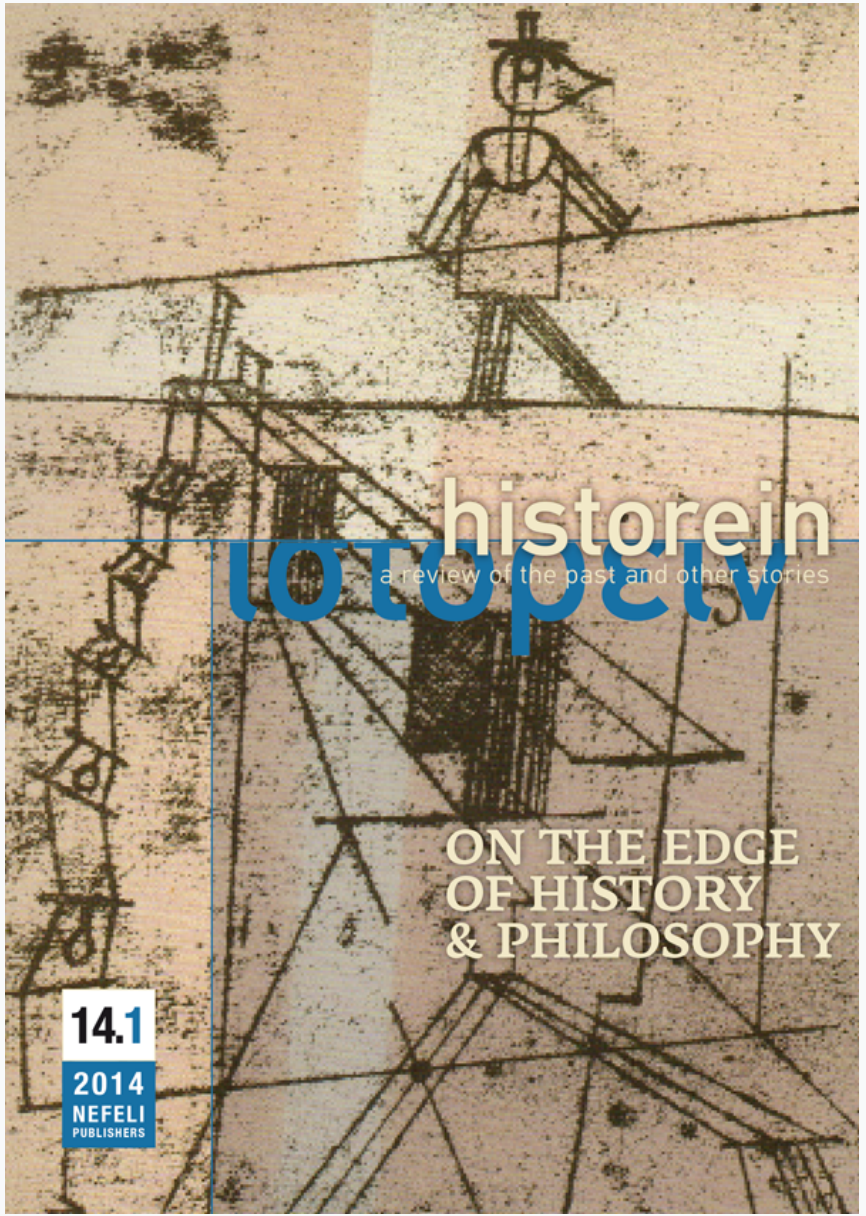

\section{Postcolonial theory and false dichotomies}

Monika Bobako

doi: $10.12681 /$ historein.212

Copyright $\odot$ 2014, Monika Bobako

\section{(c) (i) (5)}

This work is licensed under a Creative Commons Attribution-NonCommercialShareAlike 4.0.

\section{To cite this article:}

Bobako, M. (2013). Postcolonial theory and false dichotomies. Historein, 14(1), 95-97. https://doi.org/10.12681/historein.212 
The essays contained in Chris Lorenz's book Bordercrossings present a wide range of the most significant problems concerning the epistemological status of history. I would like to focus on the very conceptual framework within which those problems are identified and dissected in book. The basic framework of Lorenz's analysis is delineated, on the one hand, by the pole of objectivism and, on the other, by the pole of relativism. His declared aim is to find a way between those two extreme positions and transgress their limitations. The first, objectivist, pole is associated with naiive positivism and realism, which assumes the transparency of language, the possibility of adequate representation and the possibility of achieving ultimate unquestionable scientific truth in history. Associated with postmodernism, the second, relativist, pole is defined not only by the rejection of the ideal of objective historical knowledge and the incommensurability of systems of knowledge, but also, in some cases, by the rejection of the idea of reality being independent of representation and subject positions. One of the implications of this relativist position is depriving history of the status of a science and perceiving it rather as a kind of art or literature or as a political device. Examples of these relativist positions include Frank Ankersmit's and Hayden White's narrativist conception of history, postcolonial theory, Michel Foucault's philosophy and the range of "particularistic" histories where the subjects are women, Afro-Americans, Jews, working class or sexual minorities.

One of the reflections I had upon reading these essays was that perhaps the very conceptual framework delineated by the opposition between objectivism and positivism, and relativism and postmodernism, is no longer the best

\section{Postcolonial}

\section{theory and false dichotomies}

\section{Monika Bobako}

Adam Mickiewicz University, Poznań 
starting point for analysing the epistemological status of history. To be sure, in Lorenz's work this opposition is meant to be transgressed. However, it seems that, despite his efforts, he remains trapped within this binary conceptual structure. The very fact that it is assumed (together with the conceptual divisions like ideology/knowledge, truth/fiction, objectivity/subjectivity) as a starting point for the discussion makes it very difficult to conceptualise in a positive way the standards of post-positivist objectivity and the criteria of the validity of historians' claims to knowledge. It is because this framework is not particularly suitable for reflecting on mutual relations of history and politics, for conceptualising the way power participates in the processes of the production of historical knowledge, and for accounting for the situatedness of knowledge. In my view, the evidence of this unsuitability can be found, for example, in Lorenz's treatment of postcolonial theory and different "particularistic" histories of women, Afro-Americans, Jews, sexual minorities and so on. Lorenz locates all these histories and postcolonial theory on the relativist-postmodernist side of his spectrum of possible philosophical positions. They strongly contest the traditional notions of seemingly universalist, objectivist knowledge, so - according to the logic of the conceptual framework - they must by relativist. But the question is: can they really be classified in this way?

The problem with this classification is that - as many thinkers have shown" - radical, "judgmental" relativism is a kind of an inversion or a mirror image of positivist objectivism. It means that the binary of objectivism and relativism is, in fact, illusory. It also means that the "real" contestation of everything that is implied by positivist objectivism cannot, in fact, be based on adopting relativism. However, this fact can only be recognised if we seriously take into account the issue of power relations as an integral element of knowledge production processes and if we problematise the situatedness of these processes. Only if we do that can we see that both objectivism and relativism are the means by which it is possible to avoid talking about the situatedness of subjects of knowledge in power relations. As it is said, objectivism is a view from nowhere, from the point of god's eye. But relativism is not very different; it is a view from anywhere. Obviously, relativism is sometimes adopted as a result of the recognition that knowledge which has claimed to be universal and objective is, in fact, a particularistic expression of the views of those who dominate. So, in this sense, relativism might be considered a kind of criticism of power relations, but - as many critical epistemologists have noticed - relativism is not a position that is able to capture the epistemological interests of the dominated. Those who struggle against domination - including epistemological domination - are not interested in saying that everything is relative, simply because it would mean that there are no means by which to diagnose and measure the domination, oppression and so on. So, what remains hidden in relativism, as well as in objectivism, is the situatedness of knowledge in the relations of domination etc. (Which is not to say that relativism is never used by the dominated as a temporary tactic to undermine the structure of domination, or just to adopt to it.)

In my opinion, the misguided classification of postcolonial theory as relativist is the result of the very choice of what is a power-blind conceptual framework that positions all theories somewhere on the line stretching between (positivist) objectivism and relativism.

Obviously, a great variety of ideas and concepts are grouped under the banner of "postcolonial theory", and some of them are simply contradictory and incompatible, but what is truly the most valuable and challenging factor in postcolonial theorising is the insight that cannot be contained within 
the binary oppositions of relativism and objectivism. This insight has nothing to do with the idea of the simple revival or affirmative revalorisation of some mythical local, authentic, particular identities and knowledge - what could be interpreted as an apotheosis of relativism but which, in fact, has been denounced by many postcolonial theorists as yet another trick of colonial power. The insight I am talking about is connected with the problem of regaining a voice by the Others of Europe, but it is combined with the realisation that one of the most insidious effects of imperial and colonial power is the fact that even the forms of resistance and anticolonial struggle - in the field of politics, production of knowledge, art, literature, etc - are, to a significant extent, dictated and determined by western categories. (One of the examples might be anti-colonial nationalist struggles that were often ideologically based on the invented, quasi-local, authentic traditions, falsely believed to be ancient, that were actually mirror images of colonial representations of the colonised.)

By saying that the conceptual framework based on the opposition of objectivism/relativism is insufficient for analysing phenomena such as postcolonial theory or minority revisionist histories, I want to point out that there is a number of epistemological currents that propose alternative frameworks. Those frameworks are critical of positivist notions of objectivity, validity and universality and, at the same time, they reject relativism for the reasons I have mention above. It is in these frameworks that revisionist histories created with the focus on the position of minorities cease to be particularistic but instead can be understood as attempt at redefining pseudo-universalist, pseudo-objectivist categories that structure all kinds of scientific, academic knowledge. In this sense, they can be understood as striving for a new meaning of objectivity. I refer here, for example, to the standpoint theories represented among others by Sandra Harding, Nancy Hartsock or, in other versions, Donna Haraway. However, what is crucial in those approaches is the fact their starting point is screening and questioning the relations of power that are always at play in the production of any knowledge. In those approaches, it is assumed that what informs the content of knowledge is not only the "context of justification" but also the "context of discovery". It means that the condition of a "strong objectivity" (a new version of post-positivist objectivity) - as opposed to a "weak objectivity" of positivism - is taking into account the situatedness of knowledge and the agents of knowledge. ${ }^{2}$

\section{NOTES}

1 I am particularly inspired here by Sandra Harding's book Whose Science? Whose Knowledge? Thinking from Women's Lives, Buckingham: Open University Press, 1991.

lbid. 